\title{
Analisis Penilaian Kualitas Jenis Pelayanan Tebaik dengan Metode Analytic Network Process (ANP) di Kantor Dinas Kependudukan dan Pencatatan Sipil Kota Pematangsiantar
}

\author{
Fajar Rudi Sartomo Samosir ${ }^{1}$, Irfan Sudahri Damanik ${ }^{2}$, Dedi Suhendro ${ }^{3}$, Solikhun $^{4}$, Susiani $^{5}$ \\ 1,2,3,4,5 Jurusan Sistem Informasi, STIKOM Tunas Bangsa Pematangsiantar \\ 17fajarrudi2016@gmail.com, ${ }^{2}$ irfansudahri@gmail.com, ${ }^{3}$ dedi.su@ amiktunasbangsa.ac.id, ${ }^{4}$ solikhun@amiktunasbangsa.ac.id, \\ ${ }^{5}$ susianiatb1@gmail.com
}

Keywords:

Service Type Quality,

ANP Method,

Community Satisfaction,

Quality,

Disdukcapil,

\begin{abstract}
This study aims to determine the best service quality at the Pematangsiantar City Population and Civil Registration Office, which includes services for making Identity Cards (KTP), Family Cards (KK), birth certificates, marriage certificates and receipt making. The method used in this research is the Analytic Network Process (ANP) method. The data collection technique used is a questionnaire technique that is distributed directly to the people who come to take care of the needs of personal and family data files. The parameters used consist of the facilities provided, employee behavior, services, and provisions. Determining community satisfaction with a service can be seen from the quality of the type of service. The results of this study were obtained in rank-1 with a normal value of 0.49126400 , rank-2 family cards with a value of 0.18988000 , rank-3 birth certificates with a value of 0.16073800 , marriage certificates rank- 4 with a value of 0.09707200 and Finally, rank-5 receipt services with a value of 0.06104600 With this research it is hoped that it can help the Pematangsiantar City Population and Civil Registration Service to evaluate the services provided to the community in order to meet community expectations in terms of managing the needs of personal and family data files and knowing the types of best services.
\end{abstract}

\section{Kata Kunci}

Kualitas Jenis Pelayanan, Metode ANP.

Kepuasan Masyarakat, Kualitas,

Disdukcapil,

\section{Korespondensi Penulis:}

Fajar Rudi Sartomo Samosir, STIKOM Tunas Bangsa,

Jalan Sudirman Blok A Nomor 1, 2, 3 Pematangsiantar

Telepon: +62 82276382536

Email: fajarrudi2016@mail.com

\begin{abstract}
Penelitian ini bertujuan untuk mengetahui kualitas pelayanan terbaik di Kantor Dinas Kependudukan dan Pencatatan Sipil Kota Pematangsiantar, yang meliputi pelayanan pembuatan Kartu Tanda Penduduk (KTP), Kartu Keluarga (KK), Akta kelahiran, Akta perkawinan dan Pembuatan Resi. Metode yang digunakan dalam penelitian ini adalah Metode Analytic Network Process (ANP). Teknik pengumpulan data yang digunakan adalah teknik kuesioner yang di bagikan langsung kepada masyarakat yang datang mengurus keperluan berkas data diri dan keluarga. Parameter yang digunakan terdiri dari fasilitas yang diberikan, perilaku pegawai, pelayanan, dan ketentuan. Menentukan kepuasan masyarakat terhadap suatu pelayanan dapat diketahui dari kualitas jenis pelayanan tersebut. Hasil dari penelitian ini didapatkan di rank-1 dengan nilai normal 0,49126400, rank ke-2 kartu keluarga dengan nilai 0,18988000 , rank-3 akta lahir dengan nilai 0,16073800 , akta kawin rank-4 dengan nilai 0,09707200 dan yang terakhir pelayanan resi rank-5 dengan nilai 0,06104600 Dengan penelitian ini diharapkan dapat membantu pihak Dinas Kependudukan dan Pencatatan Sipil Kota Pematangsiantar untuk mengevaluasi pelayanan yang diberikan kepada masyarakat guna memenuhi harapan masyarakat dalam hal mengurus keperluan berkas data diri dan keluarga serta mengetahui jenis pelayanan terbaik.
\end{abstract}




\section{PENDAHULUAN}

Kualitas pelayanan dapat diketahui dengan cara membandingkan persepsi para konsumen atas pelayanan yang mereka terima dengan pelayanan yang sesungguhnya yang mereka harapkan. "Semakin baik kepemerintahan dan kualitas pelayanan yang diberikan, maka semakin tinggi kepercayaan masyarakat (high trust)".

Kepercayaan masyarakat akan semakin tinggi apabila masyarakat mendapatkan pelayanan yang terbaik dan merasa terpuaskan akan pelayanan tersebut. Pelayanan publik diberikan kepada masyarakat oleh pemerintah. Terwujudnya pelayanan publik yang berkualitas merupakan salah satu ciri dari pemerintahan yang baik sebagai tujuan dari pendayagunaan aparatur Negara.

Kantor Dinas Kependudukan dan Pencatatan Sipil (Disdukcapil) didirikan oleh Pemerintah yang mempunyai tugas pokok untuk melaksanakan urusan pemerintahan di bidang pelayanan masyarakat dalam urusan administrasi kependudukan dan pencatatan sipil, berdasarkan asas otonomi dan tugas pembantuan masyarakat. Fungsi dan tugas disdukcapil tersebut merupakan pelayanan dalam mengurus berbagai persuratan seperti membuat surat akta kelahiran, surat dokumen kependudukan, kartu keluarga (KK), akta perkawinan, surat keterangan pindah, hingga pembuatan KTP-elektronik. Kantor Dinas Kependudukan dan pencatatan sipil pematangsiantar mengutamakan kepuasan masyarakat. Pedoman Umum penyusunan Indeks Kepuasan Masyarakat Unit Pelayanan instansi Pemerintah yang terdiri dari; Prosedur pelayanan, persyaratan pelayanan, kejelasan petugas pelayanan, kedisiplinan petugas pelayanan, kecepatan pelayanan, keadilan dalam mendapat pelayanan, dan kepastian jadwal pelayanan, serta kenyamanan lingkungan. Hasil pengamatan sementara yang dilakukan penulis pada kantor Dinas kependududkan dan pencatatan sipil pematangsiantar masih terdapat beberapa dimensi kepuasan masyarakat yang belum bisa terpenuhi, yaitu kecepatan pelayanan dalam menyelesaikan pekerjaan yang di minta oleh masyarakat. Fasilitas kenyamanan lingkungan juga masih ada yang kurang memadai dan tidak mendukung berjalannya aktivitas kantor dengan baik. Jenis pelayanan yang ada pada kantor disdukcapil kota pematangsiantar adalah pelayanan pembuatan KTP, pelayanan pembuatan Resi, pelayanan pembuatan Kartu Keluarga, pelayanan pembuatan Akta Kelahiran dan pelayanan pembuatan Akta Perkawinan. Dari jenis - jenis pelayanan diatas permasalahan timbul di sebabkan oleh situasi dan kondisi dimana masyarakat sendiri masih banyak yang belum paham dalam melengkapi syarat - syarat administrasi. Banyak masyarakat menilai jenis pelayanan yang mereka dapat kurang sesuai dengan yang mereka harapkan akan tetapi ada banyak juga masyarakat yang merasa pelayanan sudah sesuai dengan yang mereka inginkan. Berdasarkan uraian diatas penulis tertarik untuk melakukan penelitian menggunakan sistem pendukung keputusan penilaian kualitas terbaik kantor disdukcapil kota pematangsiantar dengan metode ANP.

Sistem Pendukung Keputusan (SPK) metode Analytic Network Process (ANP) merupakan generalisasi dari Analytic Hierarchy Process (AHP). Metode ANP dikembangkan sebagai bentuk umum dari teori AHP yang didasarkan pada hubungan saling ketergantungan antara beberapa komponen, dimana AHP menjadi bentuk khusus dari ANP. Kelebihan metode ANP jika dibandingkan dengan metode AHP yaitu kemampuannya yang lebih bebas. Metode ANP mampu memperbaiki kelemahan metode AHP yaitu kemampuannya untuk mengakomodasi keterkaitan antara kriteria dan alternative [1].

Penelitian ini bertujuan untuk mengetahui kualitas jenis pelayanan terbaik merupakan elemen penting dalam proses evaluasi kinerja dimana tujuan akhir yang hendak di capai adalah pelayanan yang lebih baik, lebih efisien, dan lebih efektif bagi masyarakat. suatu pelayananan dinilai memuaskan bila pelayanan tersebut dapat memenuhi kebutuhan dan harapan pengguna layanan ( masyarakat).

Peneliti memanfaatkan peniliti-peniliti terdahulu sebagai referensi dalam menerapkan sistem pendukung keputusan dengan menggunakan algoritma Analytical Network Proces (ANP), beberapa penelitian terdahulu yang akan dimuat dalam bentuk tabel, sebagai berikut:

Tabel 1. Tabel Riset-Riset Terkait

\section{No Penulis}

$\begin{array}{lllr}\text { 1. } & \text { Taufik Akbar, } & \text { Mengurai } & \\ \text { Sepky } & \text { Permasalahan Audit } \\ \text { Mardian dan } & \text { Syariah } & \text { Dengan } \\ \text { Syaiful Anwar } & \text { Analytical Network } \\ & & \text { Process (ANP) [2] }\end{array}$

\section{Resume}

Penelitian yang telah dilakukan dengan menggunakan metode Analytical Network Process (ANP) mampu menguraikan permasalahan utama pada audit syariah di perbankan syariah sehingga didapatkan hasil jika masalah utama yang terdapat pada penelitian adalah regulasi, keterbatasan SDM, dan proses pada audit. 


\begin{tabular}{|c|c|c|c|}
\hline No & Penulis & Judul & Resume \\
\hline 2. & $\begin{array}{l}\text { Redi } \\
\text { Prasetiyo, } \\
\text { Sumiati dan } \\
\text { Iriani }\end{array}$ & $\begin{array}{lr}\text { Pemilihan } & \text { Supplier } \\
\text { Tembakau } & \text { Sebagai } \\
\text { Bahan Baku Rokok } \\
\text { Menggunakan } & \text { Metode } \\
\text { Analytical } & \text { Network } \\
\text { Process } \quad \text { (ANP) Di } \\
\text { Pabrik r Rokok } \\
\text { ALAINA [3] }\end{array}$ & $\begin{array}{l}\text { Berdasarkan permasalahan pada penelitian yang telah } \\
\text { dilakukan metode Analytical } \\
\text { Network Process (ANP) mampu menentukan supplier } \\
\text { terbaik dengan membandingkan keterkaitan antara kriteria - } \\
\text { kriteria yang berpengaruh sehingga hasil yang didapatkan } \\
\text { dalam bentuk perangkingan yakni Moh Asyhari berbobot } \\
1.000000 \text { sebagai rangking 1, Fatikur berbobot } 0,944074 \\
\text { rangking 2, dan Abdul basid berbobot } 0,766552 \text { rangking } 3\end{array}$ \\
\hline
\end{tabular}

3. Linda Pratiwi, Pemilihan Alternatif Penelitian yang dilakukan oleh Pratiwi et al. dengan Indriati dan Tanaman Obat melakukan penggabungan 2 metode yaitu metode anp Ahmad Afif Terhadap Penyakit sebagai pembobotan kriteria tanaman obat dan smart sebagai Supianto Hipertensi Menggunakan Metode penentuan hasil akhir dari pemilihan tanaman obat terbaik Analytical Network mampu memberikan hasil akurasi terbaik.

Process (ANP) dan

Simple Multi Attribute Rating Technique (SMART) [4]

\section{METODE PENELITIAN}

\subsection{Sistem Pendukung Kepuasan (SPK)}

Sistem Pendukung Keputusan merupakan sistem informasi berbasis komputer untuk manajemen pengambilan keputusan yang menangani masalah- masalah semi struktur [5].

Sistem pendukung keputusan ialah suatu sistem berbasis komputer yang bersifat adaptif, fleksibel dan interaktif yang digunakan untuk memecahkan masalah yang tidak-terstruktur sehingga dapat meningkatkan nilai keputusan yang diambil. Sistem pendukung keputusan (SPK) sebagai suatu sistem yang memiliki tujuan untuk membantu seorang dalam pengambilan keputusan penilaian.

\subsection{Analytical Network Process (ANP)}

Metode Analytical Network Process (ANP) merupakan suatu teknik matematik yang memungkinkan seorang pengambil keputusan dalam menghadapi suatu faktor-faktor yang saling keterhubungan (dependence) serta umpan balik (feedback) secara sistematis [6]. Metode Analytical Network Process (ANP) merupakan pengembangan dari metode yang terdahulu yaitu Analytical Hierarchy Process (AHP). [7] yakni:

Terdapat langkah-langkah yang digunakan dalam pembuatan metode Analytical Network Process (ANP)

a. Memahami masalah dan menentukan kriteria yang sesuai.

b. Menentukan pembobotan.

c. Membuat matriks perbandingan berpasangan dengan menggunakan skala perbandingan numerik 1-9 yang ditampilkan kedalam bentuk tabel sebagai berikut:

Tabel 2. Skala Numerik 1-9 Pada ANP [1]

Nilai Numerik Definisi Keterangan

\begin{tabular}{cll}
\hline 1 & Sama penting & $\begin{array}{l}\text { Kedua elemen memiliki pengaruh yang sama sisi } \\
\text { Salah satu elemen memiliki pengaruh yang sedikit lebih } \\
\text { penting dibandingkan elemen lainnya }\end{array}$ \\
5 & Sedikit lebih penting & $\begin{array}{l}\text { Salah satu elemen memiliki pengaruh yang lebih penting } \\
\text { dibandingkan elemen lainnya } \\
\text { Salah satu elemen memiliki pengaruh yang sangat lebih } \\
\text { penting dibandingkan elemen lainnya } \\
\text { Salah satu elemen mutlak memiliki pengaruh yang lebih } \\
\text { penting dibandingkan elemen lainnya } \\
\text { Suatu penilaian yang diberikan jika terdapat keraguan } \\
\text { terhadap kedua elemen }\end{array}$ \\
Sangat lebih penting & Mutlak lebih penting
\end{tabular}


d. Menghitung Eigenvector (w). Eigenvector (w) merupakan perhitungan bobot pada prioritas matriks dengan rumus:

$$
\left[\begin{array}{rl}
e_{1} & =b_{1} / \sum_{i=1}^{n} b_{i} \\
E=e_{2} & =b_{1} / \sum_{i=1}^{n} b_{i} \\
& \cdots \\
e_{i} & =b_{1} / \sum_{i=1}^{n} b_{i}
\end{array}\right]
$$

Keterangan: $e_{i}=$ menyatakan elemen matriks e baris ke-i.

e. Menghitung nilai konsisten. Apabila nilai kurang dari $10 \%$ maka nilai dapat dikatakan konsisten sehingga dapat dirumuskan sebagai berikut

$$
\begin{aligned}
& \lambda \max =\frac{\sum a}{n} \\
& C I=\frac{(\lambda \max -n)}{(n-1)} \\
& C R=\frac{C I}{R I}
\end{aligned}
$$

Keterangan:

$\lambda \max =$ Eigenvalue terbesar dari matriks berordo-n

$\mathrm{n} \quad=$ orde dari matriks

CI $\quad=$ Indeks konsistensi

RI $\quad=$ index acak untuk setiap matriks ber-ordo $\mathrm{n}$

f. Mengulang kembali langkah 3,4 dan 5 untuk setiap kriteria

g. Membuat unweighted supermatrix dengan cara memasukkan nilai eigenvector pada langkah 5 kedalam suatu supermatriks

h. Membuat weighted supermatix dengan cara mengkalikan setiap isi unweighted supermatrix dengan matriks perbandingkan kriteria (kluster matriks)

$$
\mathrm{W}_{\mathrm{w}}=\mathrm{T}_{\mathrm{z}} \cdot \mathrm{W}
$$

Keterangan:

$\begin{array}{ll}\mathrm{W}_{\mathrm{w}} & =\text { weighted supematrix } \\ \mathrm{T}_{\mathrm{z}} & =\text { matriks perbandingan } \\ \mathrm{W} & =\text { unweighted supermatrix }\end{array}$

i. Membuat limiting supermatrix dengan memangkatkan supermatrix secara berkala hingga pada disetiap kolom menghasilkan nilai yang sama besar dan menormalisasikan limiting supermatrix dengan rumus:

$$
\lim _{k \rightarrow \infty} w^{k}
$$

j. Menentukan alternatif terbaik.

\subsection{Pengertian PHP (Hypertext Preprosessor)}

PHP (Hypertext Preprosessor) adalah bahasa pemrograman yang paling banyak digunakan saat ini. PHP banyak dipakai untuk membuat situs website dinamis[8]. PHP merupakan bahasa pemrograman web yang dapat disisipkan dalam script HTML. PHP merupakan salah satu jenis scripting language yang di eksekusi pada sisi server, atau disebut server-side scripting merupakan salah satu bahasa pemrograman yang paling popular di Internet. Tag yang dapat digunakan untuk menyatakan script PHP adalah[8]:

$$
\begin{aligned}
& <? \ldots \text { ? > } \\
& <\% \ldots \%> \\
& <\text { ?php...?> }
\end{aligned}
$$

\subsection{MySQL}

MySQL merupakan sebuah implementasi dari RDBMS (Sistem Manajemen Basis Data Relasional) yang diberikan secara gratis. MySQL merupakan RDBMS yang menggunakan perintah dasar SQL (Structured Query Languange). SQL adalah sebuah konsep pengoperasian basisdata, terutama untuk pemilihan atau selesksi dan pemasukan data, yang memungkinkan pengoperasian data dikerjakan dengan mudah secara otomatis [9]. 


\subsection{Rancangan Penelitin}

Rancangan atau model penelitian disajikan dalam rancangan Flowchart pada gambar:

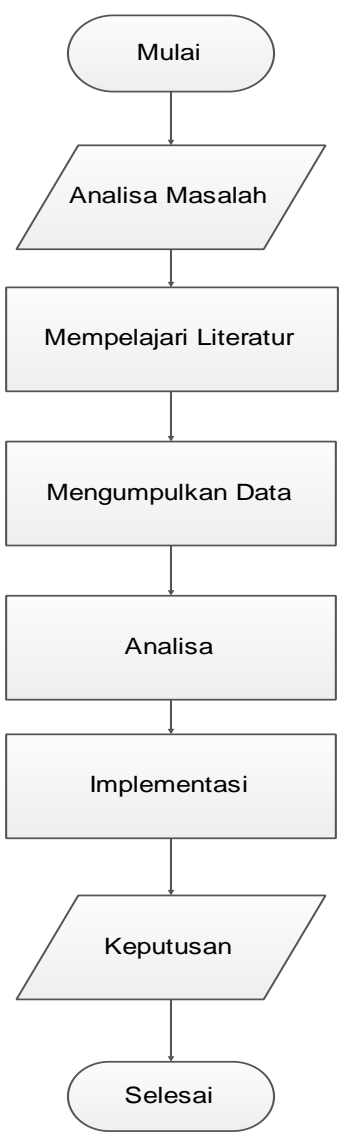

Gambar 1. Rancangan Penelitian

Gambar 1 menjelaskan rancangan penelitian yang dilakukan untuk mencari kualitas jenis pelayanan terbaik dengan menggunakan Algoritma Analytical Network Process (ANP) yang terdiri dari:

1. Analisis Masalah

Masalah yang terkait dengan kualitas jenis pelayanan di kantor disdukcapil berdasarkan masyarakat dilakukan analisa faktor-faktor yang membuat hasil kualitas jenis pelayanan terbaik kantor disdukcapil.

2. Mempelajari Literatur

Penelitian ini harus didasari rujukan yang digunakan untuk mendapatkan rujukan yang digunakan untuk mendapatkan informasi dalam penelitian.

3. Mengumpulkan Data

Data dikumpul dengan menggunakan kuesioner kepada masyarakat kota pematangsiantar yang mengurus segala keperluannya di kantor disdukcapil kota pematangsiantar Jl. Melanthon siregar selama dua minggu dari tanggal 10 Februari s/d 24 februari 2020.

4. Analisa

Proses yang dilakukan untuk mencari kualitas jenis pelayanan terbaik dengan menggunakan faktor-faktor tertentu yang digunakan.

5. Implementasi

Implementasi dilakukan dengan menggunakan program website Algoritma ANP berbasis PHP dan database MySQL sebagai sistem yang mencari keputusan dalam analisa kualitas jenis pelayanan terbaik kantor disdukcapil kota pematangsiantar.

6. Keputusan

Hasil yang diberikan oleh sistem akan ditindaklanjuti oleh pihak kantor dinas disdukcapil kota pematangsiantar agar dapat mencari solusi untuk meningkatkan kualitas pelayanan pada masyarakat yang akan mengurus keperluannya di kantor disdukcapil kota pematangsiantar.

\subsection{Analisis Data}

Pada tahapan ini berisi tentang menjelaskan suatu proses atau upaya pengolahan data menjadi sebuah informasi untuk pengambilan keputusan dan menjelaskan langkah atau bentuk alur yang dilakukan peneliti. Data diperoleh dari wawancara untuk menentukan alternatif yang digunakan dan kuesioner untuk penilaian kualitas jenis 
pelayanan terbaik di kantor Disdukcapil Kota Pematangsiantar. Data yang dikumpulkan dari kuesioner menggunakan parameter yang terdiri dari:

1. Fasiltias yang diberikan (C1) dengan sub kriteria Fasilitas yang diberikan lengkap (C11) dan Kualitas Fasilitas yang diberikan (C12).

2. Penilaian Pegawai (C2) dengan sub kriteria Perilaku pegawai ketika melayani masyarakat (C21) dan Kemampuan dan Keahlian pegawai ketika melayani masyarakat (C22).

3. Pelayanan (C3) dengan sub kriteria Pelayanan yang diberikan teratur dan disiplin (C31) dan Hasil dari jenis pelayanan yang diberikan oleh pegawai (C32).

4. Ketentuan (C4) dengan sub kriteria Waktu pengerjaan pelayananyang diberikan efisien (C41) dan Banyaknya syarat yang diberikan untuk membuat berkas (C12).

Parameter yang digunakan memiliki nilai poin setiap pilihan, data yang telah dikumpukan kemudian dikonversi menjadi nilai numeric. Nilai tersebut yang digunakan untuk penilaian pengolahan data menggunakan Algoritma ANP. Alternatif pilihan yang digunakan terdiri dari Pelayanan Pembuatan KTP, Pelayanan Pembuatan Resi, Pelayanan Pembuatan Kartu Keluarga, Pelayanan Pembuatan Akta Kelahiran dan Pelayanan Pembuatan Akta Perkawinan.

\subsection{Diagram Aktifitas Kerja Penelitian}

Alur kerja yang dilakukan penulis pada penelitian ini disajikan pada Gambar 2 dalam diagram aktivitas:

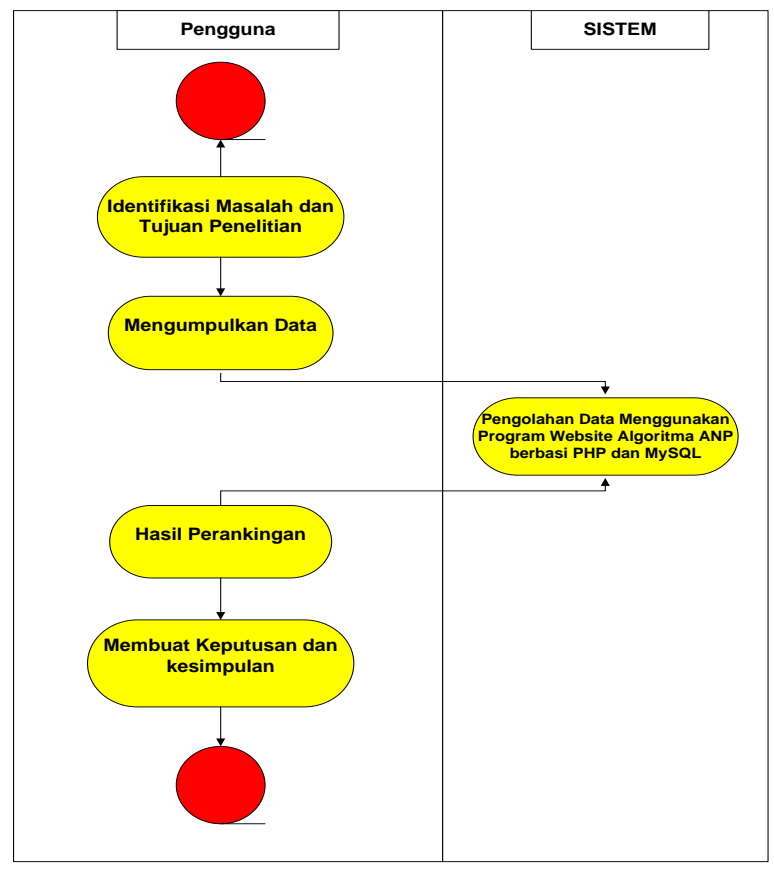

Gambar 2. Activity Diagram Penelitian

Gambar 2 merupakan alur aktivitas yang dilakukan penelitian pada sistem yang digunakan. Gambar 2 menjelaskan penulis atau pengguna mengidentifikasi masalah dan tujuan penelitian yang dilakukan, mengumpulkan data menggunakan data berupa kuesioner yang diberikan, kemudian melakukan perankingan data menggunakan website algoritma ANP. Jika data tersebut selesai maka data, hasil dari informasi yang diberikan website algoritma ANP maka penulis atau pengguna membuat rank dan analisa yang telah dilakukan. Penulis atau pengguna membuat keputusan dari hasil penelitian dan membuat kesimpulan terhadap penelitian yang dilakukan.

\section{HASIL DAN ANALISIS}

\subsection{Penerapan Algoritma ANP}

Penulis menentukan penilaian kualitas jenis pelayanan terbaik kantor Disdukcapil dengan menggunakan Algoritma ANP dengan bahasa pemrograman Website. Algoritma ANP dilakukan untuk memberikan hasil nilai tertinggi untuk menjadi acuan keputusan bahwa jenis pelayanan terbaik di kantor Disdukcapil. Berikut langkahlangkah dalam pengolahan data menggunakan Algoritma ANP:

1. Mengidentifikasi Struktur Jaringan Permasalahan

Algoritma ANP dimaksudkan untuk membantu pengambil keputusan dalam menentukan bobot ternormalisasi yang dirankingkan. 
2. Menentukan pembobotan komponen dari sudut pandang manajerial Pembobotan pada setiap komponen diberikan penilaian kepentingan relatif antara satu komponen dengan komponen lainnya.

3. Membuat Matriks Perbandingan Berpasangan.

Matriks Perbandingan Berpasangan menggambarkan kontribusi atau pengaruh setiap komponen terhadap kriteria. Perbandingan dilakukan berdasarkan penilaian dari pengambil keputusan dengan menilai tingkat kepentingan komponen.

4. Menormalisasikan Matriks Perbandingan Berpasangan

Normalisasi data pada matriks perbandingan berpasangan antar kriteria dengan cara membagikan kolom ke-i dan baris ke-j dengan jumlah pada kolom i seperti Tabel 3 berikut:

Tabel 3. Matriks Perbandingan Alternatif Terhadap Kriteria Fasilitas yang Dijumlahkan

\begin{tabular}{|c|c|c|c|c|c|}
\hline Alternatif & A1 & A2 & A3 & A4 & A5 \\
\hline A1 & 1,00 & 5,00 & 3,00 & 5,00 & 5,00 \\
\hline A2 & 0,20 & 1,00 & 0,33 & 0,33 & 0,33 \\
\hline A3 & 0,33 & 3,00 & 1,00 & 2,00 & 3,00 \\
\hline Alternatif & A1 & A2 & A3 & A4 & A5 \\
\hline A4 & 0,20 & 3,00 & 0,50 & 1,00 & 2,00 \\
\hline A5 & 0,20 & 3,00 & 0,33 & 0,50 & 1,00 \\
\hline Jumlah & 1,93 & 15 & 5,16 & 8,83 & 11,33 \\
\hline
\end{tabular}

Menormalisasikan matrik keputusan dari $a_{i j}$ kemudian dibagikan dengan jumlah pada kolom i, sebagai contoh normalisasi pada kriteria A1 (Fasilitas):

$\mathrm{a}_{11}=1,00 / 1,93=0,517$

$\mathrm{a}_{21}=0,20 / 1,93=0,103$

Seterusnya sampai normalisasi selesai ke a55, sehingga diperoleh Matriks Perbandingan Berpasangan yang dinormalisasi pada table 4:

Tabel 4. Matriks Perbandingan yang Dinormalisasi

\begin{tabular}{|c|c|c|c|c|c|}
\hline Alternatif & A1 & A2 & A3 & A4 & A5 \\
\hline A1 & 0,517 & 0,333 & 0,581 & 0,566 & 0,441 \\
\hline A2 & 0,103 & 0,067 & 0,065 & 0,038 & 0,029 \\
\hline A3 & 0,172 & 0,200 & 0,194 & 0,226 & 0,265 \\
\hline A4 & 0,103 & 0,200 & 0,097 & 0,113 & 0,176 \\
\hline A5 & 0,103 & 0,200 & 0,065 & 0,057 & 0,088 \\
\hline Alternatif & A1 & A2 & A3 & A4 & A5 \\
\hline Jumlah & 1 & 1 & 1 & 1 & 1 \\
\hline
\end{tabular}

5. Menghitung Rata-Rata Baris (Eigen Vector)

Di peroleh dengan membagikan jumlah perbaris dengan jumlah data yang dibandingkan dengan menggunakan rumus pada Persamaan 1:

Baris A1: $(0,517+0,333+0,581+0,566+0,441) / 5=\mathbf{0 , 4 4 8}$

Baris A2: $(0,103+0,067+0,065+0,038+0,029) / 5=\mathbf{0 , 0 6 0}$

6. Menghitung Weight Sum Vector

Diperoleh dengan mengalikan matriks perbandingan berpasangan dengan Eigen Vector:

Tabel 5. Weight Sum Vector

\begin{tabular}{|l|l|l|l|l|}
\hline 1,00 & 5,00 & 3,00 & 5,00 & 5,00 \\
\hline 0,20 & 1,00 & 0,33 & 0,33 & 0,33 \\
\hline 0,33 & 3,00 & 1,00 & 2,00 & 3,00 \\
\hline 0,20 & 3,00 & 0,50 & 1,00 & 2,00 \\
\hline 0,20 & 3,00 & 0,33 & 0,50 & 1,00 \\
\hline
\end{tabular}$\times$\begin{tabular}{|c|}
\hline 0,488 \\
\hline 0,060 \\
\hline 0,211 \\
\hline 0,138 \\
\hline 0,103 \\
\hline $\mathbf{2}$ \\
\hline $\mathbf{1 , 1 3 8 7}$ \\
\hline $\mathbf{0 , 7 2 7 4}$ \\
\hline $\mathbf{0 , 5 2 0 6}$ \\
\hline
\end{tabular}

7. Menghitung Consistency Vector

Diperoleh dengan membagikan Weight Sum Vector dengan Eigen Vector seperti pada tabel 6 berikut: 
Tabel 6. Consistency Vector

\begin{tabular}{|l|}
\hline 2,6264 \\
\hline 0,3085 \\
\hline 1,1387 \\
\hline 0,7274 \\
\hline 0,5206 \\
\hline
\end{tabular}

\begin{tabular}{|l|}
\hline 0,488 \\
\hline 0,060 \\
\hline 0,211 \\
\hline 0,138 \\
\hline 0,103 \\
\hline
\end{tabular}

$=$\begin{tabular}{|l|}
\hline $\mathbf{5 , 3 8 2}$ \\
\hline $\mathbf{5 , 1 4 1}$ \\
\hline $\mathbf{5 , 3 9 7}$ \\
\hline $\mathbf{5 , 2 7 1}$ \\
\hline $\mathbf{5 , 0 5 4}$ \\
\hline
\end{tabular}

8. Menghitung nilai Lamda Max

Diperoleh dengan rumus pada Persamaan 2:

Maka $\lambda \max =(5,382+5,141+5,397+5,271+5,054) / 5=5,2463$

9. Menghitung nilai Consistency Index

Menghitung nilai konsistensi index untuk setiap matriks ber-orde $n$ dengan rumus pada Persamaan 3:

Maka $C I=(5,2463-5) /(5-1)=0,0616$

10. Menghitung nilai Consistency Rasio

Terakhir menghitung konsistensi rasio (CR), perhitungan ini digunakan untuk memastikan bahwa nilai konsistensi rasio $(\mathrm{CR})<0,1$. Jika nilai konsistensi rasio $(\mathrm{CR})>0,1$ maka prose perhitungan data harus diulangi dan diperbaiki. Untuk mencari nilai index random tersebut, penulis menghitung RI sesuai dengan jumlah data yang digunakan, terdapat pada Tabel 2.1. Jika nilai CR lebih besar dari 0,1 maka matrik perbandingan berpasangan harus diperbaiki. Rumus untuk mencari nilai CR pada Persamaan 4:

Maka, CR = 0,0616 / 1,12 = 0,0550 (Konsisten)

11. Menghitung nilai terhadap semua komponen

Selanjutnya menghitung keseluruhan nilai dari setiap komponen yang terdiri dari 4 kriteria dan 5 alternatif. Untuk perhitungan yang digunakan ke supermatriks, nilai yang digunakan adalah nilai keseluruhan Eigen Vector. Berikut nilai Eigen Vector pada setiap komponen:

Tabel 7. Eigen Vector Alternatif

\begin{tabular}{ccccc}
\multirow{2}{*}{ Alternatif } & \multicolumn{4}{c}{ Eigen Vector } \\
\cline { 2 - 5 } & Fasilitas & Pegawai & Pelayanan & Ketentuan \\
\hline A1 & 0,488 & 0,491 & 0,491 & 0,492 \\
A2 & 0,06 & 0,063 & 0,063 & 0,06 \\
A3 & 0,211 & 0,187 & 0,187 & 0,188 \\
A4 & 0,138 & 0,173 & 0,173 & 0,157 \\
A5 & 0,103 & 0,086 & 0,086 & 0,103 \\
\hline
\end{tabular}

Tabel 8. Eigen Vector Kriteria

\begin{tabular}{cccccc}
\multirow{2}{*}{ Alternatif } & \multicolumn{5}{c}{ Eigen Vector } \\
\cline { 2 - 6 } & KTP & Resi & KK & Akta Lahir & Akta Kawin \\
\hline C1 & 0,097 & 0,097 & 0,097 & 0,097 & 0,097 \\
C2 & 0,097 & 0,097 & 0,097 & 0,097 & 0,097 \\
C3 & 0,252 & 0,252 & 0,252 & 0,252 & 0,252 \\
C4 & 0,555 & 0,555 & 0,555 & 0,555 & 0,555 \\
\hline
\end{tabular}

\section{Menentukan Unweighted Supermatrix}

Unweighted Supermatrix atau Supermatriks tidak terbobot didapat dengan cara memasukkan semua nilai Eigen Vector yang telah dihitung pada langkah perhitungan antar kriteria dan alternatif. Hasil Unweighted Supermatrix dapat dilihat pada tabel 9:

Tabel 9. Unweighted Supermatriks

\begin{tabular}{llllllllll} 
ANP & A1 & A2 & A3 & A4 & A5 & C1 & C2 & C3 & C4 \\
\hline A1 & 0 & 0 & 0 & 0 & 0 & 0,488 & 0,491 & 0,491 & 0,492 \\
A2 & 0 & 0 & 0 & 0 & 0 & 0,06 & 0,063 & 0,063 & 0,06 \\
A3 & 0 & 0 & 0 & 0 & 0 & 0,211 & 0,187 & 0,187 & 0,188 \\
A4 & 0 & 0 & 0 & 0 & 0 & 0,138 & 0,173 & 0,173 & 0,157 \\
A5 & 0 & 0 & 0 & 0 & 0 & 0,103 & 0,086 & 0,086 & 0,103 \\
C1 & 0,097 & 0,097 & 0,097 & 0,097 & 0,097 & 0 & 0 & 0 & 0 \\
C2 & 0,097 & 0,097 & 0,097 & 0,097 & 0,097 & 0 & 0 & 0 & 0 \\
C3 & 0,252 & 0,252 & 0,252 & 0,252 & 0,252 & 0 & 0 & 0 & 0 \\
C4 & 0,555 & 0,555 & 0,555 & 0,555 & 0,555 & 0 & 0 & 0 & 0 \\
\hline
\end{tabular}


13. Menentukan Weighted Supermatrix

Weighted Supermatrix atau Supermatriks terbobot didapat dengan cara melakukan perkalian antar isi Unweighted Supermatrix dengan cluster matrix seperti Persamaan 5. Dikarenakan hanya terdapat dua Culster yaitu Cluster Kriteria dan Cluster Alternatif dan kedua Cluster tidak diperbandingkan maka Cluster Matrix secara default seperti tabel 10 berikut:

Tabel 10. Cluster Matrix

\begin{tabular}{lcc} 
Cluster & Alternatif & Kriteria \\
\hline Alternatif & 0 & 1 \\
Kriteria & 1 & 0 \\
\hline
\end{tabular}

Sehingga hasil dari Weighted Supermatrix sama dengan Unweighted Supermatrix, seperti tabel 13 berikut:

Tabel 11. Weighted Supermatriks

\begin{tabular}{llllllllll} 
ANP & A1 & A2 & A3 & A4 & A5 & C1 & C2 & C3 & C4 \\
\hline A1 & 0 & 0 & 0 & 0 & 0 & 0,488 & 0,491 & 0,491 & 0,492 \\
A2 & 0 & 0 & 0 & 0 & 0 & 0,06 & 0,063 & 0,063 & 0,06 \\
A3 & 0 & 0 & 0 & 0 & 0 & 0,211 & 0,187 & 0,187 & 0,188 \\
A4 & 0 & 0 & 0 & 0 & 0 & 0,138 & 0,173 & 0,173 & 0,157 \\
A5 & 0 & 0 & 0 & 0 & 0 & 0,103 & 0,086 & 0,086 & 0,103 \\
C1 & 0,097 & 0,097 & 0,097 & 0,097 & 0,097 & 0 & 0 & 0 & 0 \\
C2 & 0,097 & 0,097 & 0,097 & 0,097 & 0,097 & 0 & 0 & 0 & 0 \\
C3 & 0,252 & 0,252 & 0,252 & 0,252 & 0,252 & 0 & 0 & 0 & 0 \\
C4 & 0,555 & 0,555 & 0,555 & 0,555 & 0,555 & 0 & 0 & 0 & 0 \\
\hline
\end{tabular}

14. Menentukan Limit Supermatrix

Limit Supermatrix didapat dengan cara melakukan dengan memangkatkan Weighted Supermatrix pada rumus Persamaan 6 secara terus menerus hingga angka disetiap kolom dalam satu baris sama besar, setelah itu lakukan normalisasi terhadap Limit Supermatrix sehingga seperti tabel 12 berikut:

Tabel 12. Limitit Supermatriks

\begin{tabular}{llllllllll} 
ANP & A1 & A2 & A3 & A4 & A5 & C1 & C2 & C3 & C4 \\
\hline A1 & 0,245 & 0,245 & 0,245 & 0,245 & 0,245 & 0,245 & 0,245 & 0,245 & 0,245 \\
A2 & 0,030 & 0,030 & 0,030 & 0,030 & 0,030 & 0,030 & 0,030 & 0,030 & 0,030 \\
A3 & 0,094 & 0,094 & 0,094 & 0,094 & 0,094 & 0,094 & 0,094 & 0,094 & 0,094 \\
A4 & 0,080 & 0,080 & 0,080 & 0,080 & 0,080 & 0,080 & 0,080 & 0,080 & 0,080 \\
A5 & 0,048 & 0,048 & 0,048 & 0,048 & 0,048 & 0,048 & 0,048 & 0,048 & 0,048 \\
C1 & 0,048 & 0,048 & 0,048 & 0,048 & 0,048 & 0,048 & 0,048 & 0,048 & 0,048 \\
C2 & 0,048 & 0,048 & 0,048 & 0,048 & 0,048 & 0,048 & 0,048 & 0,048 & 0,048 \\
C3 & 0,125 & 0,125 & 0,125 & 0,125 & 0,125 & 0,125 & 0,125 & 0,125 & 0,125 \\
C4 & 0,277 & 0,277 & 0,277 & 0,277 & 0,277 & 0,277 & 0,277 & 0,277 & 0,277 \\
\hline
\end{tabular}

15. Sintesa untuk mendapatkan hasil dan perankingan

Untuk mendapatkan hasil dan perankingan diambil baris pada Alternatif, untuk kolom setiap kolom sudah memiliki nilai yang sama. Kemudian menentukan nilai RAW yang diambil langsung dari Limit Supermatrix, sedangkan nilai Normal diambil dari normaliasi dengan menjumlahkan seluruh nilai kemudian dibagi nilai dengan hasil penjumalahan. Hasil Sintesa yang didapat dan perankingan dapat dilihat pada tabel 13:

Tabel 13. Hasil Sintesa Alternatif

\begin{tabular}{lccc}
\multicolumn{1}{c}{ Alternatif } & Nilai Raw & Nilai Normal & Rank \\
\hline Pelayanan Ktp & 0,24563 & 0,49126 & 1 \\
Pelayanan Resi & 0,03052 & 0,06104 & 5 \\
Pelayanan Kk & 0,09494 & 0,18988 & 2 \\
Pelayanan Akta Lahir & 0,08037 & 0,16074 & 3 \\
Pelayanan Akta Kawin & 0,04854 & 0,09708 & 4 \\
\hline
\end{tabular}




\subsection{Hasil}

Pada bagian ini berisikan tampilan sistem dengan menggunakan Algoritma ANP. Berikut tampilan dari implementasi Algoritma ANP:

1. Tampilan Utama

Tampilan Utama atau yang disebut Beranda merupakan tampilan jendela pertama yang dilihat pengguna dalam mengakses Sistem Algoritma ANP seperti pada gambar 3 berikut:

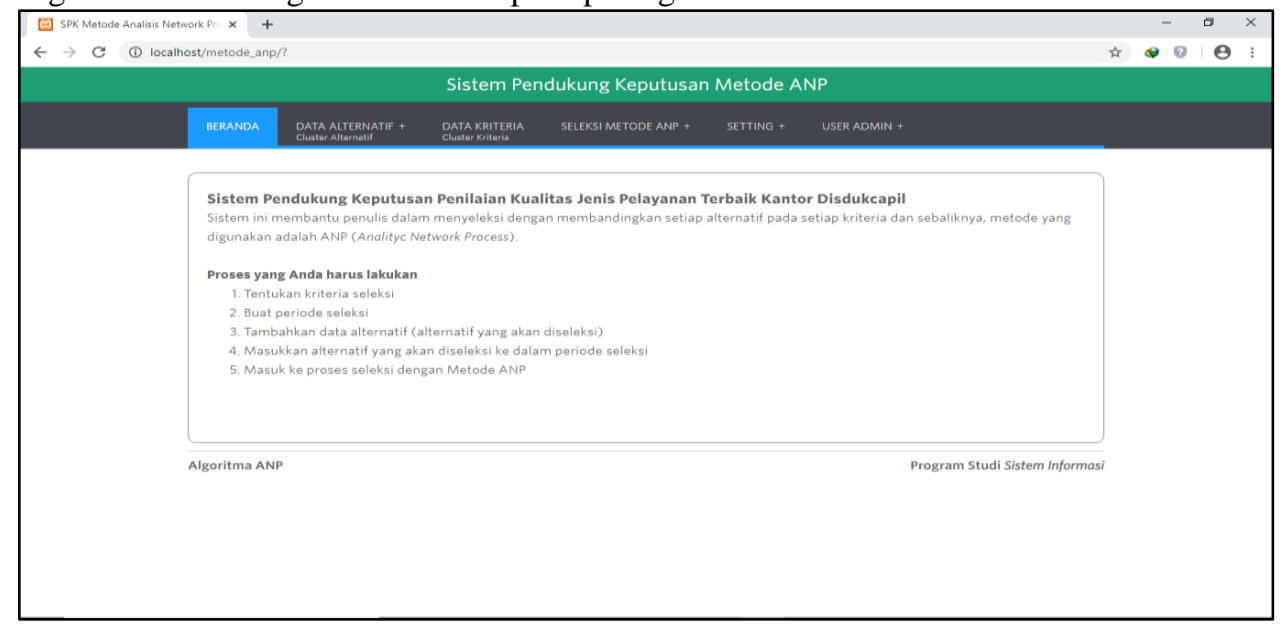

Gambar 3. Tampilan Utama Sistem Algoritma ANP

Gambar 3 menjelaskan tampilan utama menampilkan beberapa sub menu dari sistem, yang terdiri dari Data Alternatif untuk pengolahan data Alternatif, Data Kriteria untuk pengolahan data Kriteria, Seleksi Metode ANP untuk pengolahan dan perhitungan Algoritma ANP, Setting untuk mengatur seleksi dan pengguna, serta User Admin untuk mengubah password dan keluar dari Sistem Algoritma ANP.

2. Sub Menu Data Alternatif

Sub Menu Data Alternatif merupakan tampilan data alternatif yang digunakan dan diolah untuk menentukan jenis kualitas pelayanan terbaik di Kantor Disdukcapil. Data Alternatif terdiri dari nama Alternatif dan tanggal terdaftar. Tampilan dari Sub Menu Data Alternatif dapat dilihat pada gambar 4 berikut:

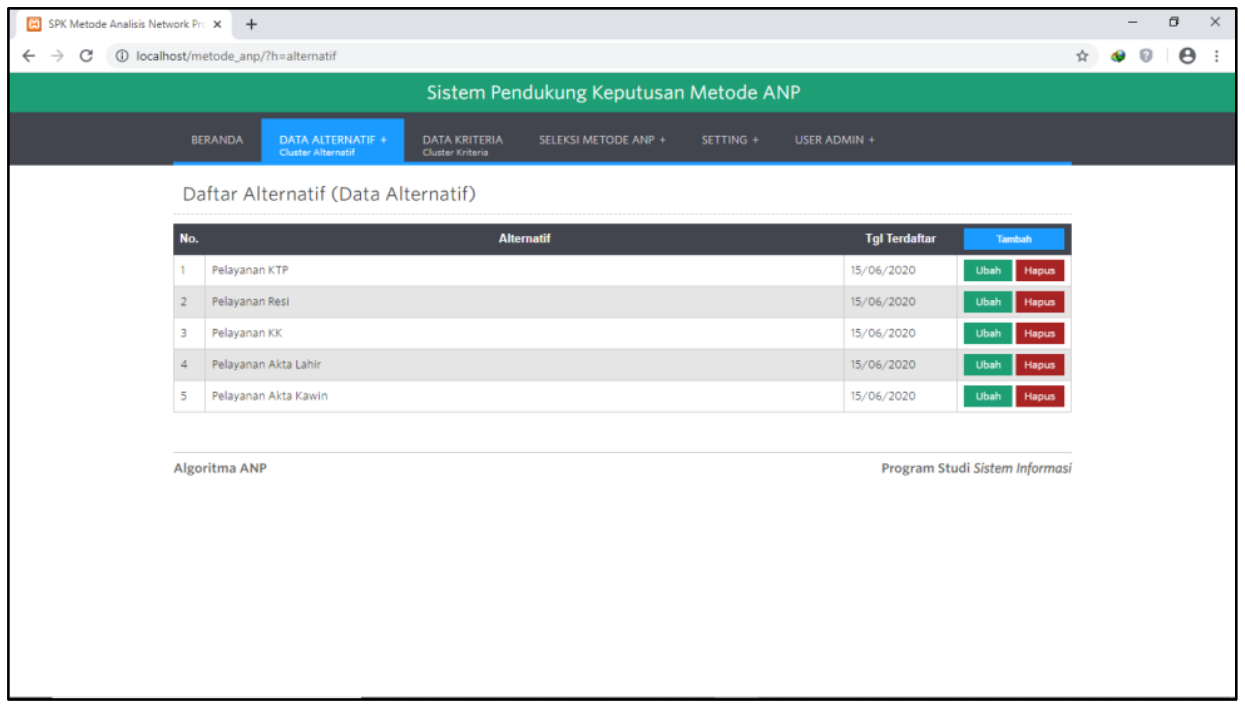

Gambar 4. Tampilan Dari Sub Menu Data Alternatif

3. Sub Menu Data Kriteria

Sub Menu Data Kriteria merupakan tampilan data kriteria yang digunakan sebagai parameter penilaian untuk menentukan jenis kualitas pelayanan terbaik di Kantor Disdukcapil. Data Kriteria terdiri dari nama Kriteria dan Keterangan Tampilan dari Sub Menu Data Kriteria dapat dilihat pada gambar 5 berikut: 


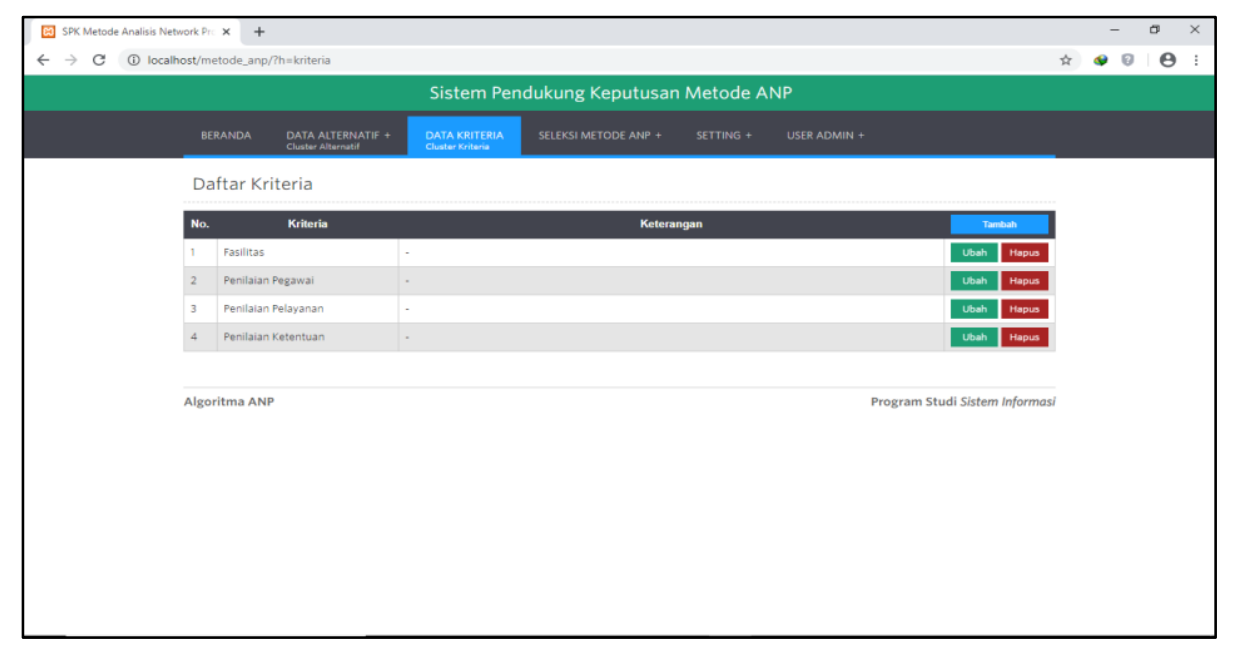

Gambar 5. Tampilan Dari Sub Menu Data Kriteria

4. Hasil Seleksi Algoritma ANP

Selanjutnya proses seleksi lainnya dilakukan sampai semua perbandingan berpasangan dinilai. Sehingga menghasilkan Unweighted Supermatrix, Weighted Supermatrix, dan Limit Supermatrix pada tampilan Hasil Seleksi pada sistem seperti berikut:

\begin{tabular}{|c|c|c|c|c|}
\hline No. & Alternatif & Tgl Daftar & Nilai Asal (RAW) & Nilai Normal \\
\hline 1 & Pelayanan KTP & $15 / 06 / 2020$ & 0,245632 & 0,49126400 \\
\hline 2 & Pelayanan KK & $15 / 06 / 2020$ & 0,094940 & 0,18988000 \\
\hline 3 & Pelayanan Akta Lahir & $15 / 06 / 2020$ & 0,080369 & 0,16073800 \\
\hline 4 & Pelayanan Akta Kawin & $15 / 06 / 2020$ & 0,048536 & 0,09707200 \\
\hline 5 & Pelayanan Resi & $15 / 06 / 2020$ & 0,030523 & 0,06104600 \\
\hline
\end{tabular}

Gambar 6. Hasil Seleksi (Perankingan)

Gambar 6 menjelaskan tampilan dari hasil seleksi yang dilakukan. Terdapat nilai tertinggi pada Alternatif Pelayanan KTP dengan nilai Asal (RAW) yaitu 0,245632 dan nilai Normal dengan nilai 0,49126400 dengan nilai tertinggi kedua pada Alternatif Pelayanan KK dengan nilai Asal (RAW) yaitu 0,094940 dan nilai Normal dengan nilai 0,18988000 .

\subsection{Validasi Data}

Hasil yang dilakukan penulis dalam perhitungan Algoritma ANP menghasilkan Alternatif Pelayanan KTP dengan nilai Asal (RAW) yaitu 0,245632 dan nilai Normal dengan nilai 0,49126400 dengan nilai tertinggi kedua pada Alternatif Pelayanan KK dengan nilai Asal (RAW) yaitu 0,094940 dan nilai Normal dengan nilai 0,18988000.

Hasil yang diberikan oleh sistem Algoritma ANP menghasilkan Alternatif Pelayanan KTP dengan nilai Asal (RAW) yaitu 0,245632 dan nilai Normal dengan nilai 0,49126400 dengan nilai tertinggi kedua pada Alternatif Pelayanan KK dengan nilai Asal (RAW) yaitu 0,094940 dan nilai Normal dengan nilai 0,18988000. Artinya Hasil dari proses yang dilakukan penulis dan sistem Algoritma ANP adalah sesuai dan sama dari proses yang dilakukan. Kesamaan hasil yang dilakukan dapat dijadikan salah satu solusi pemecahan dari permasalahan yang diteliti.

\subsection{Solusi Pemecahan Permasalahan}

Hasil yang didapatkan oleh penulis dan sistem Algoritma ANP dengan data alternatif dan kriteria yang diberikan dapat digunakan sebagai jenis pelayan terbaik pada kantor Disdukcapil yaitu pelayanan KTP. Sistem yang digunakan dapat menjadi proses penentuan pelayanan terbaik di kantor Disdukcapil berdasarkan penilaian dari masyarakat. Hasil yang diperoleh dapat membantu pihak Disdukcapil untuk meningkatkan pelayanan yang memiliki nilai paling rendah guna untuk meningkatkan kepuasan masyarakat dalam mengurus keperluan berkas data diri dan keluarga. 


\section{KESIMPULAN}

Berdasarkan pembahasan sebelumnya dapat disimpulkan bahwa metode ANP dalam menentukan jenis kualitas pelayanan terbaik dapat diketahui dengan cara membandingkan persepsi para konsumen atas pelayanan yang mereka terima. ANP merupakan pemecahan suatu masalah yang tidak terstruktur dan membutuhkan ketergantungan hubungan antara beberapa komponen dalam menunjukan kualitas jenis pelayanan yang bertujuan memuaskan masyarakat. Hasil yang didapatkan oleh penulis dan sistem Algoritma ANP dengan data alternatif dan kriteria dapat digunakan sebagai penilaian jenis pelayan terbaik pada kantor Disdukcapil yaitu pelayanan KTP berada di rank-1 dengan nilai normal 0,49126400, rank ke-2 kartu keluarga dengan nilai 0,18988000, rank-3 akta lahir dengan nilai 0,16073800, akta kawin rank-4 dengan nilai 0,09707200 dan yang terakhir pelayanan resi rank-5 dengan nilai 0,06104600 sesuai Sistem yang digunakan menjadi proses penentuan pelayanan terbaik di kantor Dinas kependudukan dan pencatatan sipil berdasarkan penilaian dari masyarakat.

\section{UCAPAN TERIMA KASIH}

Ucapan terima kasih diberikan pada STIKOM Tunas Bangsa Pematangsiantar yang telah memberikan fasilitas pada penulis, kepada Kantor Dinas Kependudukan Dan Pencatatan Sipil Kota Pematangsiantar yang telah mengizinkan penulis untuk melakukan penelitian dan kepada semua pihak-pihak yang telah membantu dalam penelitian ini.

\section{REFERENSI}

[1] A. H. Azhar and R. A. Destari, "Analisis Tingkat Kepuasan Konsumen Memilih Air Yang Layak Minum Dalam Kemasan Galon Dengan Metode ANP," vol. 6, no. 2, pp. 174-183, 2018.

[2] T. Akbar, S. Mardian, and S. Anwar, "Mengurai Permasalahan Audit Syariah dengan Analytical Network Process(ANP)," J. Akunt. Dan Keuang. Islam, vol. 2, no. 2, pp. 101-123, 2015.

[3] R. Prasetiyo, Sumiati, and Iriani, "Pemilihan Supplier Tembakau Sebagai Bahan Baku Rokok Menggunakan Metode Analytic Network Process (ANP) Di Pabrik Rokok Alaina," vol. 13, no. 01, pp. 43-54, 2018.

[4] L. Pratiwi, Indriati, and A. A. Supianto, "Pemilihan Alternatif Tanaman Obat Terhadap Penyakit Hipertensi Menggunakan Metode Analytical Network Process ( ANP) dan Simple Multi Attribute Rating Technique ( SMART )," vol. 2, no. 12, pp. 6968-6972, 2018.

[5] S. Nurhalimah, T. Tampubolon, W. B. Berutu, and J. Simarmata, "Sistem Pendukung Keputusan Penerimaan Beasiswa Pada AMIK STIEKOM Sumatera Utara Menggunakan Metode VIKOR,” pp. 753$758,2018$.

[6] A. D. Waskito, "Alternatif Pemilihan Supplierpita Sarung Tangan Golf Dengan Menggunakan Metode ANP (Studi Kasus Di CV.Sarung Tangan Pamungkas)," 2017.

[7] A. H. Azhar and R. A. Destari, "Optimasi Decision Support System ( DSS ) Pemilihan Paket Layanan Internet Prabayar Dengan Metode ANP,” vol. 3, no. September, pp. 183-192, 2019.

[8] M. S. Muarie, "Sistem Informasi Perpustakaan SMP Negeri 5 Palembang Menggunakan PHP Dan MySQL," vol. 1, no. 1, pp. 24-36, 2014.

[9] S. Lestanti and A. D. Susana, "Sistem Pengarsipan Dokumen Guru Dan Pegawai Menggunakan Metode Mixture Modelling Berbasis Web,” vol. 10, no. 2, pp. 69-77, 2016. 